Fish systematics

\title{
MORPHOLOGICAL CHARACTERISTICS OF THE MUD LOACH MISGURNUS FOSSILIS (L.) (PISCES: COBITIDAE) FROM THE MID ODRA AND VISTULA RIVER BASINS \\ CHARAKTERYSTYKA MORFOLOGICZNA PISKORZA MISGURNUS FOSSILIS (L.) (PISCES: COBITIDAE) Z DORZECZY ŚRODKOWEJ ODRY I WISLY
}

\begin{abstract}
Museum of Natural History, Wroclaw University, Poland
Morphological characteristics of $M$. fossilis was based on 139 specimens. Sexual dimorphism is manifested in 20 metric characters and in anatomical differences: structure of pectoral fins and presence of thickenings on the body sides of males. Growth of particular body parts is allometric, the main increase in the total body length falling on its mid part. Based on literature data, the material was compared with other European populations. The comparison revealed a wide variation of metric characters showing, however, no clinal pattern.
\end{abstract}

\section{INTRODUCTION}

The mud loach Misgurnus fossilis (L.) is widely distributed in Europe: from the Loire River in the west to the Volga River basin in the east. It is absent from the British Isles, Scandinavia and the Arctic Ocean basin; it does not occur in the south: Iberian, Appenninic and Balcan Peninsulas (Bănărescu 1964; Berg 1949).

Because of its low oxygen requirements, the species inhabits mainly strongly eutrophicated, muddy, stagnant and slow running waters, such as shallow, disappearing lakes, small field reservoirs, ponds, oxbows, canals and even ditches (Lelek 1987). At present, because of the extensive regulation-drainage activities which result in a disappearance of typical habitats of this species, a rapid recession of $M$. fossilis is observed in many regions of Poland, in spite of its being very abundant not long ago - especially in the east (Rolik and Rembiszewski 1987). In consequence, the mud loach is now included in the list of species under strict protection.

Little attention was devoted to $M$. fossilis in the Polish ichthyological literature. Complete information on the biometrics of the mud loach from the Biebrza River was presented by Witkowski (1984), and only some characters were considered by Białokoz (1986) who described the population from Lake Dargin. European literature on the morphology of 
the species is also scanty. Only the mud loach from the rivers of Ukraine was comprehensively studied in this respect by Movchan (1988). Besides, a biometrical characteristics was given for the populations of the Danube River basin (Oliva and Chitravadivelu 1973) and Dnepr (Žukov 1965).

The aim of this study, based on the material from the Odra and Vistula River basins, was to answer the following questions: 1) What is the variation of particular meristic and metric characters? 2) Which characters are involved in sexual dimorphism? 3) How do particular metric characters change with increasing body length? 4) Are populations of the same basin characterized by their own particular traits? 5) What is the geographic variation of meristic and metric characters in Misgurnus fossilis (L.)?

\section{MATERIAL AND METHODS}

The material included 139 specimens of Misgurnus fossilis (L.), originating from the basins of the Odra and Vistula Rivers, caught in 1889 - 1994 and kept in the collections of the Museum of Natural History, Wrocław University and the Museum and Institute of Zoology, Polish Academy of Sciences, Warsaw (Tab. 1).

Table 1

Studied material of Misgumns fossilis (L.)

\begin{tabular}{|c|c|c|c|}
\hline Locality & $\mathrm{n}$ & Period & Collectors \\
\hline \multicolumn{4}{|c|}{ Vistula River basin } \\
\hline Wierzbica $\mathrm{R}$. & 1 & Jul 1889 & Czerwiński \\
\hline Vistula $R$. & 1 & 1900 & D. Sinicyn \\
\hline Ożarów near Warsaw & 1 & 18 Jul 1928 & J. Nast \\
\hline Ziemiary near Łowicz & 2 & Jul 1929 & E. Sapiński \\
\hline Narew R. near Pulusk & 1 & 18 Dec 1929 & S. Janikowski \\
\hline Narew R. near Pultusk & 2 & 25 Jun 1930 & S. Janikowski \\
\hline Liwiec R. near Siedlce & 2 & 7-10 Aug 1930 & E. Grabda \\
\hline Gostynin & 2 & 12 Apr 1935 & S. Paraszkiewicz \\
\hline Żabieniec near Warsaw & 1 & 14 Nov 1953 & M. Gasowska \\
\hline Ponds-Gołysz near Skoczów & 1 & 12 Oct 1957 & M. Gąsowska \\
\hline Narewka R., Białowieża & 24 & 1958 & Z. Kozikowska \\
\hline Vistula Lagoon & 1 & $18-20$ Oct 1962 & J. Rembiszewski \\
\hline Ponds-Laskarzew near Garwolin & 5 & 25 Apr 1963 & J. Linkowski \\
\hline Narew R. near Różan & 1 & 6 Aug 1966 & M. Gasowska \\
\hline \multicolumn{4}{|c|}{ Odra River basin: } \\
\hline Skora R. near Grzymalin (Kaczawa basin) & 2 & 30 Мay 1985 & A. Witkowski, J. Błachuta \\
\hline Kaczawa R., ponds near Szczytniki & 12 & 21 Jun 1986 & A. Witkowski, J. Błachuta \\
\hline Polska Woda near Potaszna (Barycz basin) & 3 & 18 Jun 1991 & A. Witkowski, J. Błachuta \\
\hline Krepa R. near Barkowo (Barycz basin) & 7 & 19 Jun 1991 & A. Witkowski, J. Błachuta \\
\hline Olszówka R. near Odolanów (Barycz basin) & 37 & 26-27 May 1992 & J. Błachuta, J. Kusznierz \\
\hline Masłówka R. near Rawicz (Barycz basin) & 18 & Sep 1992 & A. Witkowski, J. Błachuta \\
\hline Czama Woda near Sobótka (Bystrzyca basin) & 15 & 15 Jun 1994 & J. Kotusz, J. Kusznierz \\
\hline
\end{tabular}

Measurements were taken according to the scheme presented by Holčik (1989). Because in the text and tables almost only character abbreviations are used, their explanations are presented below. 
List of abbreviations of meristic and metric characters used in the text (according to Holčik 1989).

I. Meristic characters: $A b$-branched rays of anal fin, $A u$-unbranched rays of anal fin, $D b$-branched rays of dorsal fin, $D u$-unbranched rays of dorsal fin, $P b$-branched rays of pectoral fin, $P u$ - unbranched rays of pectoral fin, $S p . b r$.- gill rakers, $V b$ branched rays of ventral fin, $V u$ - unbranched rays of ventral fin.

II. Metric characters: $h$-minimum body depth, $H$-maximum body depth, $h A$-depth of anal fin, $h c$-head depth, $h D$ - depth of dorsal fin, io-interorbital distance, $l A$-length of anal fin base, $l b$-length of barbel ( 1 -in mouth's angle, 2 and 3 -on upper lip, 4 and 5 - on lower lip), $l c$ - length of head, $l C$ - length of caudal fin, $I D$-length of dorsal fin, $I P$-length of pectoral fin, $l p c$-length of caudal peduncle, $I V$-length of ventral fin, $O h$-horizontal diameter of eye, $p A$-preanal distance, $p D$ - predorsal distance, $p o D$ postdorsal distance, $p o O$ - postorbital distance, $p r O$ - preorbital distance, $p V$ - preventral distance, $P-V$-distance between pectoral fin base and ventral fin base, $S l$-standard length, $T 7$-total length, $V-A$-distance between ventral fin base and anal fin base.

The fish were measured with the accuracy of $0.1 \mathrm{~mm}$. The resulting values were expressed as per cent of the standard length $(S l)$ and head length $(l c)$. Gill rakers were counted on the inner side of the first branchial arch.

Because of the strong deformation of the body of mud loach from the Vistula River basin, resulting from their long-term storage in preservation liquid, only their meristic characters were examined. The material from the tributaries of the mid Odra River was subject to a complex biometrical analysis, considering both meristic and metric characters.

Biometric characteristics was presented as mean values $(\bar{x})$, standard deviation (SD) and variation ranges of particular characters (29 metric and 9 meristic). In order to estimate the differences in variation of the characters, their variability coef cients (V) were analysed. Based on the mean value $V=7.48$ of all the metric characters calculated separately for males and females, I established three variation ranges: $\mathrm{V}<4$ - small variation, $4<\mathrm{V}<10$ medium variation, $\mathrm{V}>10$ - large variation - treated also as statistically significant, based on Ruszczyc's (1981) suggestion on the 8-10 per cent limit of statistical significance of this coefficient. Morphological differences resulting from sexual dimorphism were studied using t-Student test; verifying zero hypothesis of the absence of differences between the mean values for males and females $\left(\mathrm{H}_{0}: \bar{x}_{F}=\bar{x}_{M}\right)$ at the significance level of $\alpha=0.05$. The same test served to check the significance of the body size - dependent differences, and was performed separatelly for each sex. The length $S l=158 \mathrm{~mm}$ was adopted as the limit between large and small individuals, the mean values calculated being $S l=168 \mathrm{~mm}$ (females) and $S l=148$ (males); I did not use the arithmetic mean of the whole sample because of the uneven proportion of females and males. In order to study the variation of size-dependent 
metric characters, linear regression was analysed. In this case the zero hypothesis tested assumed independence of the variables analysed, based on the value of correlation coefficient $-r\left(\mathrm{H}_{0}: r=0, \alpha=0.05\right)$. To estimate the differences between mean values of characters in fish from three samples from the Odra River, a single factor variance analysis was applied (ANOVA single factor), and then Duncan test in order to precisely ascertain statistically significant differences between pairs of mean values $\left(\mathrm{H}_{0}: \bar{x}_{1}=\bar{x}_{2}=\bar{x}_{3}, \alpha=0.05\right)$. The studied sample from the Odra River basin (treated as a whole) was compared with populations described in the literature, by calculating the Manhattan distance matrix-for means of 22 metric characters. Based on the matrix, a dendrogram of similarities between the studied populations was constructed, using UPGMA (unweighted pir-group average) method. All the raw data are available from the author on request.

\section{RESULTS}

Morphological characteristics

Based on the analysed meristic characters (Tabs. 2-3) the studied populations can be described by almost the same formula: for the Odra basin-D III-IV (V) 5-7; $A$ III-V (4) 5-6; $V$ II 5-6 (7); $P$ I 8-11 (13); sp. br. 15-18 and Vistula basin-D III-IV (4) 5-6; $A$ III-V 5 (6); VII (5) 6-7; $P$ I 9-12; sp.br. 14-19. In both samples the following characters displayed the largest variation: $D u, D b, A u$; two characters were constant $(V u, P u)$ and four $(A b, V b, P b, s p . b r$. $)$ varied very little.

Table 2

Number of fin rays in the studied populations of Misgurnus fossilis.

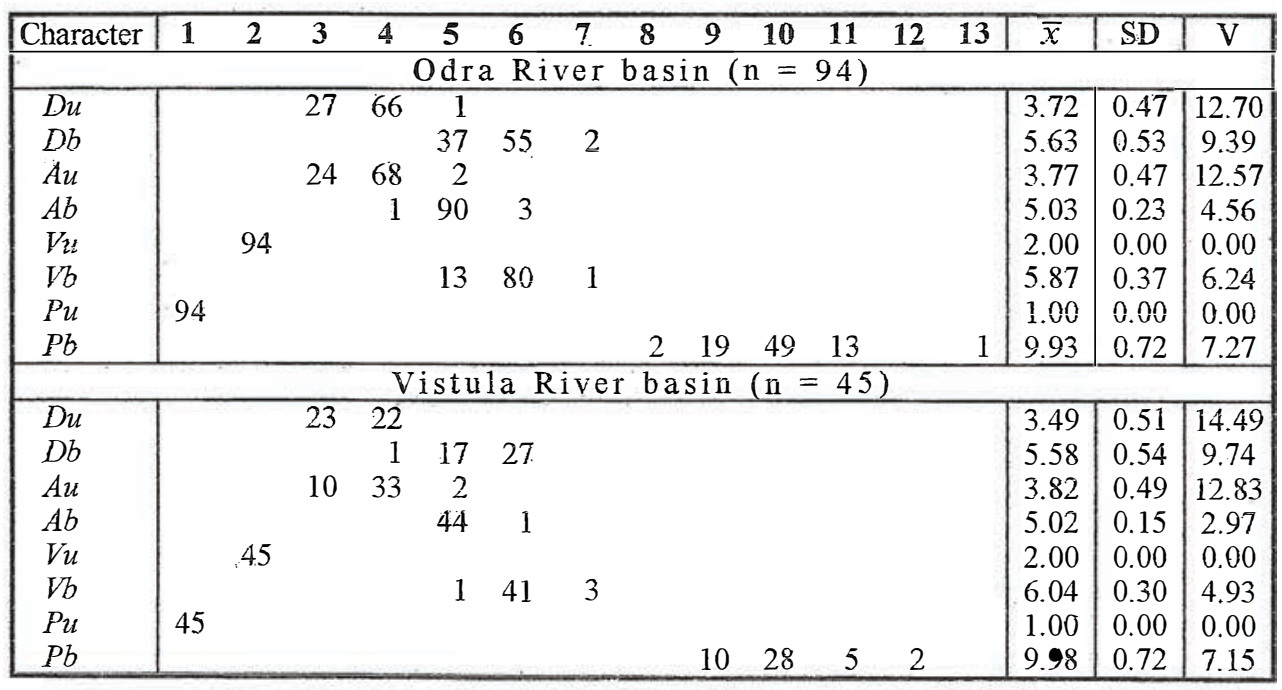


Table 3

Number of gill rakers on the first branchial arch in Misgurnus fossilis

from the Odra River $(n=93)$ and Vistula River $(n=45)$ basins

\begin{tabular}{|l|r|r|r|r|r|r|r|r|c|}
\hline Basin & $\mathbf{1 4}$ & $\mathbf{1 5}$ & $\mathbf{1 6}$ & $\mathbf{1 7}$ & $\mathbf{1 8}$ & $\mathbf{1 9}$ & $\bar{x}$ & SD & V \\
\hline Odra R. & & 15 & 53 & 20 & 5 & & 16.16 & 0.76 & 4.68 \\
Vistula R. & 3 & 6 & 17 & 13 & 4 & 2 & 16.33 & 1.17 & 7.15 \\
\hline
\end{tabular}

Table 4

Metric characters of Misgurnus fossilis from the Odra River basin $(\mathrm{n}=94)$

\begin{tabular}{|c|c|c|c|c|}
\hline Character & range & $\bar{x}$ & SD & $\bar{V}$ \\
\hline$S l(\mathrm{~mm})$ & $94-236$ & 156 & 29.65 & 19.05 \\
\hline \multicolumn{5}{|c|}{ in $\% S l$} \\
\hline Tl & $106.95-116.23$ & 113.57 & 1.55 & 1.37 \\
\hline$l c$ & $14.71-18.92$ & 16.42 & 0.88 & 5.38 \\
\hline$p D$ & $54.68-61.89$ & 58.44 & 1.45 & 2.48 \\
\hline$p o D$ & $31.17-37.92$ & 34.31 & 1.29 & 3.76 \\
\hline$p V$ & $55.27-61.82$ & 58.51 & 1.44 & 2.46 \\
\hline$p A$ & $69.44-77.14$ & 74.01 & 1.67 & 3.01 \\
\hline$H$ & $11.52-15.17$ & 13.44 & 0.79 & 5.90 \\
\hline$h$ & $8.09-11.64$ & 10.07 & 0.88 & 8.75 \\
\hline $\operatorname{lpc}$ & $15.42-21.38$ & 18.29 & 1.26 & 7.64 \\
\hline ID & $5.72-8.18$ & 7.01 & 0.56 & 7.95 \\
\hline$h D$ & $7.42-12.28$ & 9.37 & 0.88 & 9.36 \\
\hline$l A$ & $5.00-8.15$ & 6.64 & 0.60 & 9.06 \\
\hline$h A$ & $7.31-10.64$ & 8.98 & 0.83 & 9.42 \\
\hline$l P$ & $8.82-17.08$ & 11.95 & 2.28 & 19.11 \\
\hline$\overline{l V}$ & $6.50-13.10$ & 8.88 & 1.05 & 11.83 \\
\hline$\overline{P-V}$ & $38.00-46.65$ & 41.64 & 1.76 & 4.22 \\
\hline$V-A$ & $12.48-17.99$ & 15.48 & 1.07 & 8.73 \\
\hline$l C$ & $10.28-16.49$ & 13.79 & 1.17 & 8.47 \\
\hline \multicolumn{5}{|c|}{ in $\% l c$} \\
\hline $\mathrm{prO}$ & $36.95-46.10$ & 41.53 & 1.80 & 4.34 \\
\hline$O h$ & $8.56-13.40$ & 11.09 & 1.06 & 14.48 \\
\hline$p o O$ & $42.05-53.56$ & 49.67 & 1.62 & 3.26 \\
\hline hc & $49.44-63.94$ & 57.15 & 2.80 & 4.90 \\
\hline io & $20.82-28.73$ & 24.84 & 1.93 & 7.79 \\
\hline $1 b 1$ & $18.92-42.15$ & 29.43 & 4.23 & 14.37 \\
\hline $1 b 2$ & $16.67-42.86$ & 30.00 & 4.32 & 14.41 \\
\hline 163 & $22.79-46.43$ & 34.19 & 4.46 & 13.03 \\
\hline $1 b 4$ & $5.67-17.94$ & 11.05 & 2.34 & 21.20 \\
\hline 165 & $2.41-7.64$ & 4.67 & 0.97 & 20.76 \\
\hline
\end{tabular}

Metric characters are presented in Tab. 4. As a result of significant differences caused by sexual dimorphism, the variation was analysed based on variability coefficient calculated for each sex separately (Tab. 5). All the characters that show a large (statistically significant) variation are associated with the head length $(l b 1, l b 2, l b 3, l b 4, l b 5$, Oh). Among the parameters of medium variation, three were associated with the head length ( $p r O, h c$, io) and 12 with the body length $(l c, H, h, l p c, l D$, $h D, l A, h A, l P, l V, V-A$, lC). Narrow variation was displayed by one character associated with the head length ( $p o O)$ and six associated with the body length (Tl, $p D, p o D, p V, p A)$. 
Table 5

Metric characters of females and males of Misgurnus fossilis from the Odra River basin

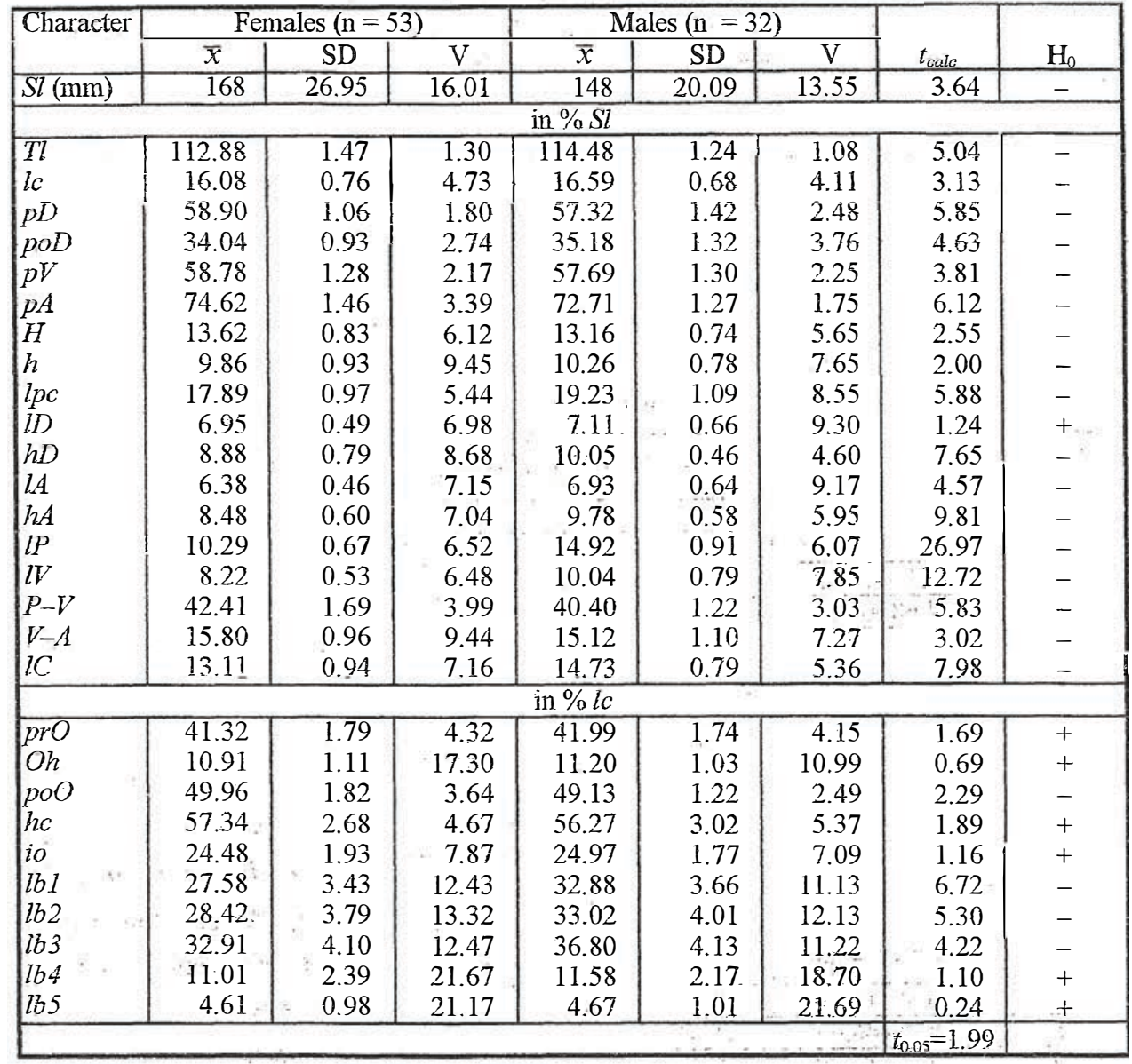

$\mathrm{H}_{0}$ : confirmed (+), rejected (-).

Sexual dimorphis m

Sexual dimorphism is expressed in most of the studied metric characters (Tab. 5). Females are characterized by higher mean values of the following characters: $S l, p D, p V, p A$, $H, P-V, V-A, p o O$; in males these characters are: $T l, l c, p o D, h, l p c, h D, l A, h A, l P, l V, l C$, $b b 1, l b 2, l b 3$. The largest differences are those in the length of paired fins, which in males are distinctly longer than in females (for $l P, t=26.97 ; l V, t=12.72$ at $t_{0,05}=1.99$ ). Because the difference between the mean body length in females $(S l=168 \mathrm{~mm})$ and males $(S I=148 \mathrm{~mm})$ also proved statistically significant, characters in which size-dependent sexual dimorphism is expressed were examined. The test reveals that ten of them are at the same time size-dependent (Tab. 6), but only in the case of $l c$ and $h$ such differences are 
Table 6

Characters that show significant difference between large (L) and small (S) individuals of $M$. fossilis

\begin{tabular}{|c|c|c|}
\hline \multirow{3}{*}{ Character } & Females & Males \\
\hline & $\mathrm{L}(\mathrm{n}=35) \mid \mathrm{S}(\mathrm{n}=18)$ & $\mathrm{L}(\mathrm{n}=7) \mid \mathrm{S}(\mathrm{n}=25)$ \\
\hline & $t_{\text {calc }}$ & $t_{\text {calc }}$ \\
\hline \multicolumn{3}{|c|}{ in $\% S l$} \\
\hline$\overline{T i}$ & 2.09 & $\overline{\mathrm{aS}}$ \\
\hline l.c & 6.01 & 2.32 \\
\hline$h$ & 3.14 & ns \\
\hline$h D$ & 3.91 & ns \\
\hline$h A$ & 2.92 & ns \\
\hline$l P$ & 3.71 & ns \\
\hline$P-V$ & -2.35 & ns \\
\hline$V-A$ & -3.03 & ns \\
\hline $2 C$ & 2.08 & ns \\
\hline \multicolumn{3}{|c|}{ in $\% l c$} \\
\hline$\overline{l b 4}$ & 2.38 & ns \\
\hline & $t_{0.05}=2.01$ & $t_{0.05}=2.04$ \\
\hline
\end{tabular}

value higher in $\mathrm{L}(-)$, statistically non-significant (ns). stronger expressed than those resulting from sexual dimorphism. In the remaining eight characters $t$ values for the size-dependent differences are significantly lower than those for males and females, which suggests that they are specific for sexual dimorphism. Irrespective from metric characters, sexual dimorphism is expressed as a distinct thickening of the body sides behind the dorsal fin in males, in the shape of pectoral fins (triangular outline in males, rounded in females) and thicker first soft ray in these fins in males.

\section{Size-dependent variation}

Rectilinear regression for absolute values of particular metric characters versus body length or head length shows a distinct positive correlation in all the studied cases. Its variation between particular characters is reflected in the value of correlation coefficient $(r)$ which is within the range of 0.407 (Ib5) to 0.997 (for $T l$ ) (Tab. 7). The regression for percentage coefficients of the characters versus the same independent variables $(S l, l c)$ reveals an allometric growth of 15 parameters. With increasing body length and head length relative values of 13 characters decrease $(T l, l c, h, h D, l A, h A, l P, l V, l C, O h, l b 2, l b 3, l b 5)$, whereas values of two $(P-V, V-A)$ increase. This means that the main increase in the total length of the mud loach falls on the mid part of the body (contained between the bases of $P$ and $A$ ). These conclusions are largely supported by the results of comparison of large and small fish presented in Tab. 6.

Variation within the Odra River basin population

The fish from three different tributaries of the mid Odra River were treated as independent samples, not showing statistically significant differences between each other with respect to meristic and most (21) metric characters. Characters which display non-uniformity of mean values are: $l c, p r O, h c, i o, l b 2, l b 3, i b 4, l b 5$, and the fish of the Barycz River basin differ from the fish of the Bystrzyca River basin in six characters ( $l c$, $h c$, io, $l b 3, l b 4, I b 5)$; from the sample from the Kaczawa River basin in four characters ( $l c$, io, $l b 2, l b 5$ ); whereas specimens from the Kaczawa and Bystrzyca basins differ significantly only in two characters ( $p r O, l b 2)$. 
Table 7

Correlation coefficient ( $r$ ) and parameters of linear regression equations: $y=b x+a$. describing dependence of particular characters on $S l$. and $l c$ in $M$. fossilis $(\mathrm{n}=94)$

\begin{tabular}{|c|c|c|c|c|c|c|c|c|c|}
\hline$x$ & $y$ & $b$ & $a$ & $r$ & $\mathrm{H}_{0}: r=0$ & $b$ & $a$ & $r$ & $\mathrm{H}_{0}: r=0$ \\
\hline & & \multicolumn{4}{|c|}{$y$ in $\mathrm{mm}$} & \multicolumn{4}{|c|}{$y$ in $\% s l$} \\
\hline$S I$ & $T l$ & 1.091 & 6.76 & 0.997 & - & -0.026 & 117.58 & -0.488 & - \\
\hline$S l$ & $l c$ & 0.125 & 5.84 & 0.980 & - & -0.025 & 20.26 & -0.829 & - \\
\hline$S l$ & $p$ & 0.578 & 0.90 & 0.991 & - & -0.061 & 59.39 & -0.124 & + \\
\hline$S$ & poD & 0.345 & -0.33 & 0.983 & - & 0.005 & 33.58 & 0.107 & + \\
\hline$S l$ & $p V$ & 0.580 & 0.82 & 0.991 & - & -0.006 & 59.41 & -0.119 & + \\
\hline$S I$ & $p A$ & 0.753 & -1.98 & 0.993 & - & 0.006 & 73.15 & 0.099 & + \\
\hline$S l$. & $H$ & 0.141 & -0.94 & 0.956 & - & 0.004 & 12.85 & 0.142 & + \\
\hline$S l$ & $h$ & 0.082 & 2.87 & 0.885 & - & -0.012 & 11.93 & -0.402 & - \\
\hline$S I$ & $l p c$ & 0.182 & 0.21 & 0.943 & - & 0.001 & 18.12 & 0.026 & + \\
\hline$S I$ & $1 D$ & 0.070 & -0.04 & 0.925 & - & 0.001 & 6.89 & 0.043 & + \\
\hline$S t$ & $h D$ & 0.640 & 4.51 & 0.843 & - & 0.018 & 12.14 & -0.585 & - \\
\hline$S I$ & $I A$ & 0.052 & 2.12 & 0.878 & - & -0.008 & 7.93 & -0.407 & - \\
\hline$S l$ & $h A$ & 0.067 & 3.37 & 0.853 & - & -0.012 & 10.91 & -0.447 & - \\
\hline$\$ 1$ & IP & 0.071 & 7.31 & 0.538 & - & -0.027 & 16.12 & -0.347 & - \\
\hline$S l$ & $I V$ & 0.070 & 2.84 & 0.798 & - & -0.010 & 10.45 & -0.285 & - \\
\hline$S l$ & $P-V$ & 0.458 & -6.35 & 0.980 & - & 0.024 & 37.92 & 0.403 & - \\
\hline$S l$ & $V-A$ & 0.178 & -3.43 & 0.958 & - & 0.014 & 13.32 & 0.384 & - \\
\hline \multirow[t]{2}{*}{ Sll } & $1 C$ & 0.102 & 5.51 & 0.883 & - & -0.022 & 17.23 & -0.556 & - \\
\hline & & \multicolumn{4}{|c|}{$y$ in $\mathrm{mm}$} & \multicolumn{4}{|c|}{$y$ in $\% l c$} \\
\hline$l c$ & $\mathrm{prO}$ & 0.449 & -0.83 & 0.966 & - & 0.115 & 38.62 & 0.202 & $t$ \\
\hline$l c$ & $O h$ & 0.093 & 0.44 & 0.802 & - & -0.095 & 13.68 & -0.220 & - \\
\hline$l c$ & $p o O$ & 0.497 & 0.00 & 0.975 & - & 0.001 & 49.63 & 0.003 & + \\
\hline ic & $h c$ & 0.607 & -0.90 & 0.956 & - & 0.127 & $53 . \overline{33}$ & 0.074 & + \\
\hline$l c$ & io & 0.248 & 0.02 & 0.894 & - & -0.019 & 25.33 & -0.038 & + \\
\hline$l c$ & $I b 1$ & 0.198 & 2.40 & 0.587 & - & -0.340 & 38.04 & -0.304 & + \\
\hline$l c$ & $1 b 2$ & 0.195 & 2.61 & 0.571 & - & -0.355 & 39.01 & -0.312 & - \\
\hline$l c$ & 163 & 0.242 & 2.48 & 0.637 & - & -0.341 & 42.83 & -0.290 & - \\
\hline$l c$ & $1 b 4$ & 0.100 & 0.25 & 0.536 & - & -0.018 & 11.51 & -0.030 & + \\
\hline \multirow[t]{2}{*}{ Ic } & 165 & 0.028 & 0.46 & 0.407 & - & -0.069 & 6.43 & -0.270 & - \\
\hline & & \multicolumn{4}{|c|}{$r_{0.05}=0.205$} & \multicolumn{4}{|c|}{$r_{0.05}=0.205$} \\
\hline
\end{tabular}

$\mathrm{H}_{0}$ : confirmed $(+)$, rejected $(-)$.

\section{DISCUSSION}

Sexual dimorphism in the mud loach is clearly expressed in a few characters. Thickenings of the body sides, longer pectoral fins and the thickened first soft ray of these fins, as characteristic of males, were reported by Rolik and Rembiszewski (1987), Movchan (1988) and Oliva and Chitravadivelu (1973). The authors of the last two papers, as well as Štědronský (1948), Oliva (1956) and Vladykov (1928, 1931), listed other sexually dimorphic characters which were also observed in the studied material: longer ventral ins, more triangular pectoral fins in males (rounded in females) and longer body in females. Movchan 
(1988) studied differences in metric characters between males and females of the sample from the Northern Donets River basin, obtaining results similar to those reported for the mud loach from the Odra River. The analysis of my own materials revealed, furthermore, a sexual dimorphism in the following characters: $l c, I D, I A, V-A$, poO. Some dimorphic characters reported in the Polish literature, such as distinctly thickened second ray in ventral fins and tapered dorsal fin in males (Gassowska 1962; Białokoz 1986), were not observed in the examined specimens from the tributaries of the Odra and Vistula River basins. Those authors did not mention any character pertaining to the structure of pectoral fins.

The size-dependent variation of metric characters was studied by Movchan (1988) in the populations from the Northem Donets River basin; that author divided all the specimens into fractions grouped around means $S l=157.9 \pm 1.4 \mathrm{~mm}$, and $S l=189.5 \pm 3.3 \mathrm{~mm}$, and then studied significance of differences between means of particular metric characters. In this way he demonstrated higher values of $l c, h D, l A, h A, l C$, in small individuals, and of $p A, P-V$ in large individuals. Only one of the parameters $(p A)$ shows a dependence on the body length different from that in the population from the Odra River basin, where $p A$ is ideally positively correlated with $S l$.

Meristic characters of the mud loach in both the studied samples are close to values describing other populations from European waters. The number of hard rays in the dorsal and anal fins seems, however, to be somewhat higher (Tab. 2) than in the fish from the rivers: Danube $-D=2.7, A=3.0$ (Oliva and Chitravadivelu 1973); Biebrza- $D=3.2$, $A=3.11$ (Witkowski 1984); Dnepr (only for $D$ )—range 2-4 (Zukov 1965) and from the Lake Dargin $-D=3, A=3$ (Białokoz 1986). The range (3-4), but without the mean value of the character, reported by Movchan (1988) for the mud loach from the rivers of Ukraine, does not permit conclusions about possible differences. The number of gill rakers was given only for the rivers of Ukraine (12-17) and the Lake Dargin (11-13), and it is lower than in the mud loach from the Odra (15-18) and Vistula (14-19) River basins. The remaining meristic characters show differences only compared to the fish from the Lake Dargin, where each had a lower (and constant) value.

A high specificity was demonstrated for metric characters of particular populations from the rivers of Ukraine (Movchan 1988). Considerable differences between them pertain both to fish from basins situated far from each other (S. Bug [Boh]-N. Donets, Desna-Danube and others) and neighbouring (Danube-Dnestr, S. Bug [Boh]-Desna), or even inhabiting the same basin (S. Danube-Transcarpathian rivers). The dendrogram based on the matrix, considering the hitherto described populations (Žukov 1965; Witkowski 1984; Movchan 1988) and the population from the Odra River basin, to a considerable degree confirms observations of Movchan (1988). However, at the same time it reveals a group of populations which are distinctly similar: basins of the rivers Biebrza and Odra, Transcarpathian rivers 
and lower Dnestr River basin, and a high separateness of populations from the basins of the rivers Dnepr, Desna, N. Donets, Danube and S. Bug [Boh] (Fig. 1). Comparative analysis of my own results and literature data does not indicate any clinal variation and testifies to a wide variability of metric characters of the mud loach.

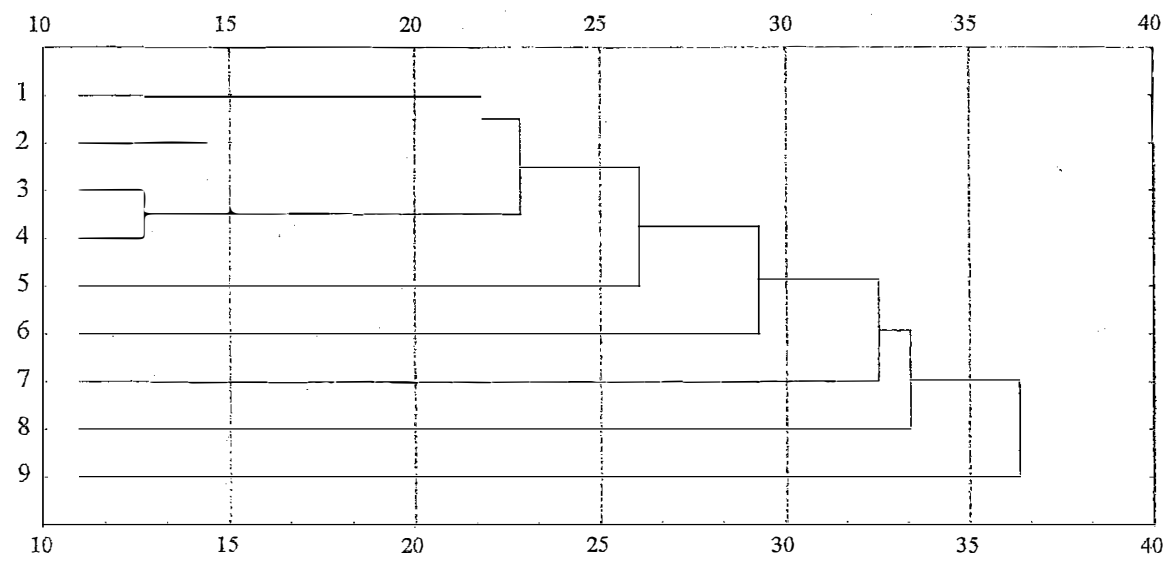

Fig. 1. A UPGMA (unweighted pair-group method with arithmetic averaging) dendrogram based on the Manhattan distance of 9 European populations of $M$. fossilis 1-Biebrza R., 2-Odra basin, 3-Transcarpathian rivers, 4-Lower Dnestr basin, 5-Dnepr basin, 6-Desna basin, 7-North Donets basin, 8-Danube R., 9-South Bug [Boh] basin.

\section{CONCLUSIONS}

1. Morphological characteristics of the mud loach of the mid Odra and Vistula river basins: $D$ III-IV (V) (4) 5-7; $A$ III-V (4) 5-6; V II 5-7; P I 8-12 (13); sp. br. 14-19.

2. Of the metric characters only the length of barbels $(l b 1-5)$ and horizontal diameter of eye $(O h)$ show a statistically significant variation (Tab. 5).

3. Sexual dimorphism is expressed in 20 metric characters. Females have higher mean values of the following characters: $S l, p D, p V, p A, H, P-V, V-A, p o O$; and males: $T l, l c$, $p o D, h, l p c, h D, l A, h A, l P, l V, l C, l b 1, l b 2, l b 3$ (Tabs. 5-6); dimorphism involves also anatomical differences: structure of pectoral fins and presence of a thickening on the body sides in males.

4. Growth of 15 body measurements is allometric. The following characters grow slower than the body length $(S l): T l, l c, h, h D, l A, h A, l P, l V, l C, O h, l b 2, l b 3, l b 5$; while $P-V$, $V-A$, increase quicker; thus the main growth of the total length of fish falls on its mid part (contained between $P$ and $A$ ) (Tab. 7). 
5. Populations of the three tributaries of the Odra River basin show particular characters expressed in the following measurements: $l c$, prO, $h c$, io, $l b 2, l b 3, l b 4, l b 5$.

6. No distinct clinal variability has been found between the mud loach populations from various European waters, though there exists a group of populations of a clear morphological similarity: basins of the rivers Biebrza and Odra, Transcarpathian rivers and lower Dnestr River basin, and a high separateness of populations from the basins of the rivers Dnepr, Desna, N. Donets, Danube and S. Bug [Boh] (Fig. 1).

\section{REFERENCES}

Bănărescu P., 1964: Pisces - Osteichthyes. Fauna RPR, 13, Acad. RPR, Bucuresti. (In Roumunian).

Berg L. S., 1949: Ryby presnych vod SSSR i sopredelnych stran. 2. Izd. Akad. Nauk SSSR, Moskva-Lenigrad, 469-925. (In Russian).

Białokoz W., 1986: Piskorz, Misgurnus fossilis (Linnaeus, 1758). W: Brylińska, M. (red.) - Ryby Słodkowodne Polski [Weather - fish, M. fossilis (L.). In: Brylińska, M. (ed.) - Freshwater fishes of Poland.]. PWN, Warszawa, 327-330. (In Polish).

Gąsowska M., 1962: Klucze do oznaczania kręgowców Polski. Część I. Kragłouste - Cyclostomi i Ryby - Pisces. [The key for defining vertebrates of Poland. Part I. Cyclostomates and Fishes]. PWN, Warszawa. (In Polish).

Holčik J. (ed.), 1989: The Freshwater Fishes of Europe. Vol. 1. Part. 2. General introduction to fishes. Acipenseriformes. Aula Verl., Wiesbaden.

Lelek A., 1987: The Freshwater Fishes of Europe. 9. Threatened Fishes of Europe. Wiesbaden, Aula Verl. (ed. Europ. Committee for the Conservation of Nature and Natural Resources).

Movchan Yu.V., 1988: Fauna Ukrainy. T. 8. Ryby. vyp. 3. Naukova Dumka, Kiev. (In Russian).

Oliva O., 1956: P̆̌spěvky k systematické revisi některých našich ryb. C̆as. Nár. Mus., 124: 70-74. (In Czech).

Oliva, O., K.Chitravadivelu, 1973: Morphometrical note on the weather-fish, Misgurnus fossilis (Linnaeus, 1758) (Osteichthyes - Cobitidae). Vest. Česk. Spol. Zool., 37: 257-281.

Rolik H., J. M. Rembiszewski, 1987: Ryby i Kragłouste. 5. Fauna Słodkowodna Polski. [Fishes and Cyclostomates. 5. Freshwater Fauna of Poland]. PWN, Warszawa. (In Polish).

Ruszczyc $\mathbb{Z}$., 1981: Metodyka doświadczeń zootechnicznych. [Methodology of experiments in animal husbandry]. PWRiL, Warszawa. (In Polish).

Štědronský E., 1948: Druhotné pohlavné znaky u piskoře a střevle. Sbor. ČAZ, 20: 384-390. (In Czech).

Vladykov V., 1928: Über sekundären Geschlechtsdimorfismus bei unseren Cobitiden. Zool. Jahrb., Abt. f. Syst., 55: 147-162.

Vladykov V., 1931: Poissons de la Russie Sous-Carpathique (Tchécoslovaquie). Mém. Soc. Zool. France, 29: 217-374.

Witkowski A., 1984: Analiza ichtiofauny basenu Biebrzy. Cz. 1. Charakterystyka morfologicznosystematyczna smoczkoustych i ryb. [An analysis of the ichthyofauna of the Biebrza River basin. Part I. The morphological and systematical characteristic of lampreys and fishes.]. Acta Univ. Wrat., 646. Pr. Zool., 14: 1-110. (In Polish with English summary).

Zukov, P. I., 1965: Ryby Belorusii. Nauka i Technika. Minsk: 331-336. (In Russian). 


\section{Jan KOTUSZ}

\section{CHARAKTERYSTYKA MORFOLOGICZNA PISKORZA MISGURNUS FOSSILIS (L.) (PISCES: COBITIDAE) Z DORZECZY ŚRODKOWEJ ODRY I WISLY}

\section{STRESZCZENIE}

Analize morfologiczną piskorza, Misgurnus fossilis (L.) z dorzeczy środkowej Odry (n = 94) i Wisty $(n=45)$ rzeprowadzono w oparciu o 9 cech merystycznych i 29 wymierzalnych.

Istotną statystycznie zmienność spośród cech wymierzalnych wykazują jedynie: dhugość wąsików $(l b l-5)$ oraz średnica horyzontalna oka $(O h)$.

Dymorfizm płciowy ujawnia się w 20 cechach wymierzalnych. Samice odznaczają się większymi średnimi wartościami następujących cech: długości ciała $(S l)$, odległości przedgrzbietowej $(p D)$, odległości przedbrzusznej $(p I)$, odległości przedodbytowej $(p A)$, największej wysokości ciała $(H)$, odległości między podstawą pletw piersiowych i brzusznych $(P-h)$, odległości między podstawą płetwy brzusznej i odbytowej $(V-A)$, odległości zaocznej $(p o O)$; samce - dhugości ciala $(T t)$, odleglości zagrzbietowej $(p o D)$, długości trzonu ogona $(l p c)$, wysokości płetwy grzbietowej $(h D)$, dhugości podstawy płetwy odbytowej $(l A)$, wysokości pletwy odbytowej $(h A)$, długości płetwy piersiowej $(I P)$, długości pletwy brzusznej (IV), długości płetwy ogonowej $(I C)$, długości wąsików - w kącikach ust $(l b I)$ i dwóch par na szczęce gómej $(l b 2, l b 3)$. Ponađto występują różnice w ksztalcie płetw piersiowych (są one trójkątne u samców i owalne u samic), budowie pierwszego promienia miękkiego w płetwach piersiowych (grubszego u samców) i w obecności u samców zgrubienia na bokach ciała za pletwą grzbietowa.

Wzrost poszczególnych części ciała nie jest równomierny; główny przyrost całkowitej dhugości ryby przypada na partię środkową - zawartą między nasadami $P$ i $A$.

W obrębie populacji z dorzecza Odry wykazano cechy swoiste w trzech próbach pochodzących z różnych dopływów, ujawniające się w 8 wymiarach: długości głowy (lc), odległości przedocznej (prO), wysokości głowy $(h c)$, odległości międzyocznej (io), długości wąsików na szczęce górnej ( $l b 2$, $l b 3)$, długości obydwu par wąsików na szczęce dolnej (lb4, lb5).

Opierając się na danych z literatury porównano badany materiał $M$. fossilis z innymi europejskimi populacjami. Nie wykazano u tego gatunku zmienności klinalnej, wskazano jednak grupe populacji o wyraźnym podobieństwie z: Biebrzy, dorzecza Odry, rzek Zakarpacia i dorzecza Dolnego Dniestru oraz dużą odrębność populacji z dorzẹczy Dnicpru, Desny, Pólnocnego Dońca, Dunaju i Południowego Bugu.

Received: 10 May 1995

Author's address:

Jan Kotusz MSc

Museum of Natural History

Wroclaw University

Sienkiewicza 21, 50-335 Wroclaw, Poland 